\title{
Design, Synthesis and Anti-tubulin Activity of Novel Dinitro Diphenyl Ether Derivatives as Potent Anticancer Agent
}

\section{Li-Fei Bai', Hui-Hong Qian', Da-Wei Jiang ${ }^{1}$, Xiao-Ming Wang ${ }^{2}$ and Ren-Lei Wang ${ }^{1 *}$}

${ }^{1}$ Jiangsu Key Laboratory of Biofunction Molecule, School of Life Science and Chemical Engineering, Jiangsu Second Normal University, Nanjing 210013, China ${ }^{2}$ State Key Laboratory of Pharmaceutical Biotechnology, School of Life Sciences, Nanjing University, Nanjing, 210093, China

\begin{abstract}
In this study, a series of Dinitrodiphenyl Ether derivatives (1b-5b) were synthesized and their biological activities were also evaluated as potential tubulin inhibitors. Among them, compound $3 b\left(\mathrm{IC}_{50}=1.26 \pm 0.84 \mu \mathrm{M}\right)$ exhibited the most potent anti-proliferative activity of MCF-7 cancer cell line in vitro, which was comparable to that of colchicine $\left(\mathrm{IC}_{50}=0.93 \pm 0.46 \mu \mathrm{M}\right)$ as reference. And it also showed the most potent growth inhibitory activity against tubulin $\left(\mathrm{IC}_{50}=5.10 \pm 0.81 \mu \mathrm{M}\right)$, which was also compared with colchicine $\left(\mathrm{IC}_{50}=3.42 \pm 0.63 \mu \mathrm{M}\right)$. Molecular docking simulation results demonstrated that $3 \mathrm{~b}$ could bind to the colchicine binding site of tubulin and effectively inhibit tubulin polymerization. Moreover, the subsequent cell cycle arrest and apoptosis assay further confirmed that $3 \mathrm{~b}$ could cause MCF-7 cell cycle arrest in the middle and later stages of mitosis and thus leading to cell apoptosis. To sum up, we recommend $3 \mathrm{~b}$ as the best candidate of potential anti-cancer agent among these new compounds. Based on the preliminary results, compound $3 \mathrm{~b}$ with potent inhibitory activity in tumor growth may be a potential anti-cancer agent.
\end{abstract}

Keywords: Anti-cancer; Dinitrodiphenyl ether derivatives; Antitubulin

\section{Introduction}

Microtubules are major cytoskeletal components of eukaryotic cells that are involved in multiple cellular processes [1]. It always combined with other protein to assemble spindle, centriole, flagellum, nerviduct etc. Microtubules are critical elements in a variety of fundamental cell functions, including sustained shape, transportation of vesicles and protein complexes, and regulation of motility and cell division [2]. Small molecules inhibitors can cause mitotic arrest and induce apoptosis via interfere with the dynamics of tubulin polymerization and depolymerization. Hence, microtubules have become an attractive pharmacologic target for anticancer drug discovery [3].

The three characterized binding sites of tubulin are the taxane, vinca alkaloid and colchicine sites [4]. The well-characterized clinically used microtubule inhibitors are the taxanes and the Vinca alkaloids. Taxanes, such as paclitaxel and docetaxel, are newer antimitotic agents that stabilize microtubules and induce a net polymerization. The established class of Vinca alkaloids, such as vincristine, vinblastine, and vinorelbine, bind to the tubulin dimer, block the formation of new microtubules, and lead to the depolymerization of existing microtubules [5]. However, the colchicine binding site inhibitors that are successfully used in clinical tumor treatment has not been reported.

The first colchicine site inhibitor, colchicine, was extracted from the poisonous meadow saffron Colchicum autumnale L, but its high toxicity has limited its therapeutic applications [6]. Combretastatin A-4 (CA-4), a natural product isolated by Pettit and co-workers in 1982 from the South African bush willow tree Combretum caffrum, strongly inhibits the polymerization of tubulin by binding to the colchicine site [7]. However, CA-4 exerts potent cytotoxicity against a variety of human cancer cells including multidrug resistant (MDR) cancer cell lines. Despite its very potent cytotoxic and antitubulin activities in vitro, CA-4 as an antimitotic agent showed poor antitumor effects in vivo models due to its poor water solubility [8]. Given that, the researchers have to looking for other CA-4 analogues which can address its limitations $[9,10]$.
It is widely reported that Schiff's base is a promising skeleton that has shown the good antitubulin activity. It displays a variety of biological activities, such as anti-cancer, anti-inflammatory, antituberculosis, anti-fungal, activities, and as herbicide [11,12]. Their broad biological properties are largely due to the exocyclic $-\mathrm{RC}=\mathrm{N}$ bond. The introduction of substituents to the terminal bonds of Schiff's base remains an area of pharmacological interest to activate Schiff's base. For instance, Zhao et al. synthesized a series of 2,6-dinitro-4(trifluoromethyl) phenoxysalicylaldoxime derivatives which share the similar part with it [13]. And among them, compound $2 \mathrm{~h}$ showed the most potent anti-proliferative activity against cancer cell lines in vitro and significant tubulin polymerization inhibitory activity. The author considered that the incorporation of 1,3-dinitro-5(trifluoromethyl) benzene could contribute to the binding of target compounds with tubulin. Because trifluoromethyl possess lipophilicify to penetrate the cell membrane. And the isosteric substitution of hydrogen by the strong electron-withdrawing effect of $\mathrm{CF} 3$ groups may increase the lipophilicity and thus enhance the rate of cell penetration, which is a very important feature in drug delivery in vivo, referring to prokaryotic as well as eukaryotic cells.

Meanwhile, dinitrobenzene, a widely used chemical fragment, always been considered to drug design. Zhao et al. synthesized a series of flavone and isoflavone derivatives which contains dinitrobenzene moiety and evaluated them as kinesin spindle protein inhibitors [14]

*Corresponding author: Ren-Lei Wang, Jiangsu Key Laboratory of Biofunction Molecule, School of Life Science and Chemical Engineering, Jiangsu Second Normal University, Nanjing 210013, China, Tel: +862583758339; E-mail: 12201103@jssun.edu.cn

Received December 15, 2017; Accepted December 19, 2017; Published December 26, 2017

Citation: Bai L, Qian H, Jiang D, Wang X, Wang R (2017) Design, Synthesis and Anti-tubulin Activity of Novel Dinitro Diphenyl Ether Derivatives as Potent Anticancer Agent. Med Chem (Los Angeles) 7: 393-397. doi: 10.4172/2161-0444.10486

Copyright: @ 2017 Bai L, et al. This is an open-access article distributed under the terms of the Creative Commons Attribution License, which permits unrestricted use, distribution, and reproduction in any medium, provided the original author and source are credited. 
George et al. reported that the Dinitrodiphenyl Ether sulfonamides shows antikinetoplastid antimitotic activity and can increase metabolic stability against parasites [15]. Though structure-activity relationship analysis, Fennell et al. synthesized a series of antimalarial agent which contain Dinitrodiphenyl Ether moieties and determined the target as tubulin [16].

Our current work continues efforts to design and synthesize a series of Dinitrodiphenyl Ether compounds as novel heterocyclic CA-4 analogs and to evaluate their biological activities for further drug development. These compounds strongly inhibited the growth of cancer cell lines and tubulin polymerization by binding to the colchicine site of tubulin and caused cells to arrest in the G2/M phase of the cell cycle.

\section{Experiment}

\section{Materials and measurements}

All chemicals and reagents used in current study were analytical grade. Thin layer chromatography (TLC) was performed on the glassbacked silica gel sheets (Silica Gel 60 GF254) and visualized in UV light $(254 \mathrm{~nm})$. Separation of the compounds by column chromatography was carried out with silica gel 60 (200-300 mesh ASTM, E. Merck). The quantity of silica gel used was 50-100 times the weight charged on the column. Melting points were determined on an XT4 MP apparatus (Taike Corp., Beijing, China). All the Proton nuclear magnetic resonance (1H NMR) spectra were recorded on a Bruker PX500 or DPX300 model Spectrometer in DMSO- $\mathrm{d}_{6}$ at $25^{\circ} \mathrm{C}$ with TMS and chemical shifts were reported in parts per million (d). The solvent signals allotted as internal stands. Elemental analyses were performed on a $\mathrm{CHNeO}-\mathrm{Rapid}$ instrument. All the compounds gave satisfactory chemical analyses $( \pm 0.4 \%)$.

\section{General procedure for the synthesis of compounds $1 \mathbf{b}-5 \mathbf{b}$}

N- (4- (2,6-dinitro-4- (trifluoromethyl)phenoxy) - 3methoxybenzylidene)-2-methylaniline (1b): Yellow powder, yield $78.2 \%, \mathrm{mp}: 89-90^{\circ} \mathrm{C}$. $1 \mathrm{H} \mathrm{NMR}\left(300 \mathrm{MHz}, \mathrm{CDCl}_{3}\right): \delta 8.78(\mathrm{~s}, 2 \mathrm{H}, \mathrm{Ar}-$ $\mathrm{H}), 8.20(\mathrm{~s}, 1 \mathrm{H}, \mathrm{C}-\mathrm{H}), 7.15-7.05(\mathrm{~m}, 6 \mathrm{H}, \mathrm{Ar}-\mathrm{H}), 6.90(\mathrm{~d}, \mathrm{~J}=12.1 \mathrm{~Hz}, 1 \mathrm{H}$, $\mathrm{Ar}-\mathrm{H}), 4.09$ (s, 3H, Ar-O-CH $), 2.15$ (s, 3H, Ar-CH $)$. ESI-TOF, calcd for $\mathrm{C}_{22} \mathrm{H}_{16} \mathrm{~F}_{3} \mathrm{~N}_{3} \mathrm{O}_{6}\left([\mathrm{M}+\mathrm{Na}]^{+}\right) 498.2320$, found 498.1562. Anal. Calcd for $\mathrm{C}_{22} \mathrm{H}_{16} \mathrm{~F}_{3} \mathrm{~N}_{3} \mathrm{O}_{6}: \mathrm{C}, 55.58 ; \mathrm{H}, 3.39 ; \mathrm{N}, 8.84$; Found: $\mathrm{C}, 55.69 ; \mathrm{H}, 3.48 ; \mathrm{N}$, 8.92 .

N-(4-(2,6-dinitro-4-(trifluoromethyl)phenoxy)-3methoxybenzylidene)-2-fluoroaniline (2b): Yellow powder, yield $68.8 \%, \mathrm{mp}: 84-86^{\circ} \mathrm{C}$. $1 \mathrm{H} \mathrm{NMR}\left(300 \mathrm{MHz}, \mathrm{CDCl}_{3}\right): \delta 8.82(\mathrm{~s}, 2 \mathrm{H}, \mathrm{Ar}-$ $\mathrm{H}), 8.25$ (s, 1H, C-H), 7.10-7.02 (m, 6H, Ar-H), 6.98(d, J=11.7 Hz, 1H, $\mathrm{Ar}-\mathrm{H}), 4.25$ (s, 3H, Ar-O-CH $), 2.19$ (s, 3H, Ar-CH $)$. ESI-TOF, calcd for $\mathrm{C}_{21} \mathrm{H}_{13} \mathrm{~F}_{4} \mathrm{~N}_{3} \mathrm{O}_{6}\left([\mathrm{M}+\mathrm{Na}]^{+}\right)$502.3420, found 502.2584. Anal. Calcd for $\mathrm{C}_{21} \mathrm{H}_{13} \mathrm{~F}_{4} \mathrm{~N}_{3} \mathrm{O}_{6}$ : C, 52.62; H, 2.73; N, 8.77; Found: C, 52.89; H, 2.68; N, 8.72 .

N-(4-(2,6-dinitro-4-(trifluoromethyl)phenoxy)-3methoxybenzylidene)-2,4-difluoroaniline (3b): Yellow powder, yield $88.5 \%$, mp: $86-87^{\circ} \mathrm{C}$. $1 \mathrm{H} \mathrm{NMR}\left(300 \mathrm{MHz}, \mathrm{CDCl}_{3}\right): \delta 8.90$ (s, $2 \mathrm{H}, \mathrm{Ar}-$ H), 8.29(s, 1H, C-H), 7.18-7.09 (m, 6H, Ar-H), 6.98(d, J=12.5 Hz, $1 \mathrm{H}$, $\mathrm{Ar}-\mathrm{H}$ ), 3.99 (s, 3H, Ar-O-CH $), 2.15$ (s, 3H, Ar-CH $)$. ESI-TOF, calcd for $\mathrm{C}_{21} \mathrm{H}_{12} \mathrm{~F}_{5} \mathrm{~N}_{3} \mathrm{O}_{6}\left([\mathrm{M}+\mathrm{Na}]^{+}\right) 520.3325$, found 520.2893. Anal. Calcd for $\mathrm{C}_{21} \mathrm{H}_{12} \mathrm{~F}_{5} \mathrm{~N}_{3} \mathrm{O}_{6}: \mathrm{C}, 50.72 ; \mathrm{H}, 2.43 ; \mathrm{N}, 8.45$; Found: $\mathrm{C}, 50.77 ; \mathrm{H}, 2.50 ; \mathrm{N}, 8.62$.

3-bromo-N-(4-(2,6-dinitro-4-(trifluoromethyl)phenoxy)3-methoxybenzylidene)-5 (trifluoromethyl)aniline (4b): Yellow powder, yield $80 \%, \mathrm{mp}: 90-92^{\circ} \mathrm{C} .1 \mathrm{H} \mathrm{NMR}\left(300 \mathrm{MHz}, \mathrm{CDCl}_{3}\right): \delta 8.85$ (s, $2 \mathrm{H}, \mathrm{Ar}-\mathrm{H}), 8.23(\mathrm{~s}, 1 \mathrm{H}, \mathrm{C}-\mathrm{H}), 7.16-7.05$ (m, 6H, Ar-H), 6.86 (d, J=11.9
$\mathrm{Hz}, 1 \mathrm{H}, \mathrm{Ar}-\mathrm{H}$ ), 3.90 (s, 3H, Ar-O-CH $\left.{ }_{3}\right), 2.28$ (s, 3H, Ar-CH3). ESITOF, calcd for $\mathrm{C}_{22} \mathrm{H}_{12} \mathrm{BrF}_{6} \mathrm{~N}_{3} \mathrm{O}_{6}\left([\mathrm{M}+\mathrm{Na}]^{+}\right)$631.2410, found 631.2522. Anal. Calcd for $\mathrm{C}_{22} \mathrm{H}_{12} \mathrm{BrF}_{6} \mathrm{~N}_{3} \mathrm{O}_{6}$ : C, 43.44; $\mathrm{H}, 1.99 ; \mathrm{N}, 6.91$; Found: $\mathrm{C}$, $43.50 ; \mathrm{H}, 2.10 ; \mathrm{N}, 7.12$.

$N^{\prime}-(4-(2,6-d i n i t r o-4-(t r i f l u o r o m e t h y l) p h e n o x y)-3-$ methoxybenzylidene)benzohydrazide (5b): Yellow powder, yield 65\%, mp: $83-85^{\circ} \mathrm{C} .1 \mathrm{H} \mathrm{NMR}\left(300 \mathrm{MHz}, \mathrm{CDCl}_{3}\right): \delta 8.86(\mathrm{~s}, 2 \mathrm{H}, \mathrm{Ar}-\mathrm{H})$, 8.24(s, 1H, C-H), 7.14-7.00 (m, 6H, Ar-H), 6.84(d, J=11.2 Hz, 1H, Ar$\mathrm{H}), 3.95$ (s, 3H, Ar-O-CH $), 2.20$ (s, 3H, Ar- $\mathrm{CH}_{3}$ ). ESI-TOF, calcd for $\mathrm{C}_{22} \mathrm{H}_{15} \mathrm{~F}_{3} \mathrm{~N}_{4} \mathrm{O}_{7}\left([\mathrm{M}+\mathrm{Na}]^{+}\right)$527.3712, found 527.3805. Anal. Calcd for $\mathrm{C}_{22} \mathrm{H}_{15} \mathrm{~F}_{3} \mathrm{~N}_{4} \mathrm{O}_{7}$ : C, 52.39; H, 3.00; N, 11.11; Found: C, 52.50; H, 3.10; N, 11.23 .

\section{Anti-proliferation activity}

The anti-proliferation activity of the prepared compounds against three cancer cell lines, MCF-7, A549 and MDA-MB-231 and one normal cell line, L02 were evaluated as described elsewhere with some modifications. Target tumor cell line was grown to log phase in DMEM medium supplemented with $10 \%$ fetal bovine serum. After diluting to $2 \times 10^{4}$ cells $\mathrm{mL}^{-1}$ with the complete medium, $100 \mu \mathrm{L}$ of the obtained cell suspension was added to each well of 96 -well culture plates. The subsequent incubation was permitted at $37^{\circ} \mathrm{C}, 5 \% \mathrm{CO}_{2}$ atmosphere for 24 hours before the cytotoxicity assessments. Tested samples at preset concentrations were added to 6 wells with colchicine as positive reference because it can bind to the active site of tubulin nicely. After 48 hours exposure period, $40 \mu \mathrm{L}$ of PBS containing $2.5 \mathrm{mg} \mathrm{mL}-1$ of MTT (3-(4, 5-dimethylthiazol-2-yl)-2, 5-diphenyltetrazolium bromide)) was added to each well. Four hours later, $100 \mu \mathrm{L}$ extraction solutions $(10 \%$ SDS-5\% isobutyl alcohol-0.01 M HCl) was added. After an overnight incubation at $37^{\circ} \mathrm{C}$, the optical density was measured at a wavelength of $570 \mathrm{~nm}$ on a microplate reader ELx 800 (BioTek, Highland Park, Winooski, VT, USA). In all experiments three replicate wells were used for each drug concentration. Each assay was carried out at least three times. The results are summarized in Table 1.

\section{Effects on tubulin polymerization assay}

To evaluate the effect of the compounds on tubulin assembly in vitro, varying concentrations were pre-incubated with $10 \mu \mathrm{M}$ tubulin in glutamate buffer at $30^{\circ} \mathrm{C}$ and then cooled to $0^{\circ} \mathrm{C}$. After addition of GTP, the mixtures were transferred to $0^{\circ} \mathrm{C}$ cuvettes in a recording spectrophotometer and warmed-up to $30^{\circ} \mathrm{C}$ and the assembly of tubulin was observed turbid metrically. The $\mathrm{IC}_{50}$ was defined as the compound concentration that inhibited the extent of assembly by $50 \%$ after 20 minutes incubation.

\section{Cell cycle assay}

MCF-7 cells were plated in 6-well plates $\left(5.0 \times 10^{3}\right.$ cells/well $)$ and incubated at $37^{\circ} \mathrm{C}$ for 24 hours. Exponentially growing cells were then incubated with the compound $3 \mathrm{~b}$ at $1 \mu \mathrm{M}, 3 \mu \mathrm{M}$ and $10 \mu \mathrm{M}$. Untreated cells (control) or cells treated with the compounds solvent (DMSO) were included. DMSO was used at the highest concentration used in the experiments. After then, cells were centrifuged and fixed in $70 \%$ ethanol at $4^{\circ} \mathrm{C}$ for at least 12 hours and subsequently resuspended in PBS containing $0.1 \mathrm{mg} \mathrm{mL}^{-1} \mathrm{RNase} A$ and $5 \mu \mathrm{g} \mathrm{mL}^{-1}$ propidium iodide (PI). Cellular DNA content, for cell cycle distribution analysis, was measured by flow cytometry using FACNcan cytofluorometer (PT. Madagasi Brosa Inc. JI. Batang Hari NO.73, Propinsi Sumatera Utara, Indonesia) plotting at least 20,000 events per sample. The percentage of cells in the G1, S and G2/M phases of the cell cycle and the percentage of cells in the sub-G1 peak were determined using the Flowjo 7.6.1 
software after cell debris exclusion.

\section{Apoptosis}

For Annexin V/PI assays, MCF-7 cells were stained with Annexin V-FITC and PI and then monitored for apoptosis by flow cytometry. Briefly, $0.5 \times 10^{6}$ cells were washed with PBS and stained with $5 \mu \mathrm{L}$ of Annexin V-FITC and $2.5 \mu \mathrm{L}$ of PI $(5 \mu \mathrm{g} \mathrm{mL}-1)$ in $1 \mathrm{x}$ binding buffer $(10$ mM HEPES, pH 7.4, $140 \mathrm{mM} \mathrm{NaOH}, 2.5 \mathrm{mM} \mathrm{CaCl}_{2}$ ) for 30 minutes at room temperature in the dark. Apoptotic cells were quantified using a FACScan cytofluorometer (PT. Madagasi Brosa Inc. Jl. Batang Hari No. 73, Propinsi Sumatera Utara, Indonesia.). Statistical analysis was done using Flowjo 7.6.1 software. Both early apoptotic (AnnexinVpositive, PI-negative) and late apoptotic (double positive of Annexin V and PI) cells were detected.

\section{Results and Discussion}

\section{Chemistry}

The synthesis of Dinitrodiphenyl Ether derivatives followed the general reaction pathway outlined in Scheme 1. $0.1 \mathrm{~mol}$ vanillina and $0.1 \mathrm{~mol}$ phenylamine derivatives were dissolved in $50 \mathrm{~mL}$ ethyl alcohol and refluxing for a few hours until vanillina disappeared. Then, cooling the solution to room temperature to afford the pure products (1a-5a). After then, $0.01 \mathrm{mmol}$ 4-trifluoromethyl-3,5-dinitrochlorobenzene and $0.01 \mathrm{mmol} 1 \mathrm{a}-5 \mathrm{a}$ were dissolved in $20 \mathrm{~mL}$ DMF and stirred at room temperature for several hours. Then, pouring it into ice and stirring until the solution was dissolved in ice-water completely. After filtering, raw products were obtained and recrystallized to offered pure drugs (1b-5b) and the chemical structures were shown in Figure 1. All the compounds were reported for the first time. All of the synthetic compounds gave satisfactory analytical and spectroscopic data. $1 \mathrm{H}$ NMR and ESI-MS spectra were consistent with the assigned structures.

\section{Bioassay}

Anti-proliferative activity: All synthesized Dinitrodiphenyl Ether derivatives $1 b-5 b$ were evaluated for their ability of anti-proliferative activities against three cancer cell lines, MCF-7, A549 and MDAMB-231 and one normal cell lines, L02. The results are summarized in

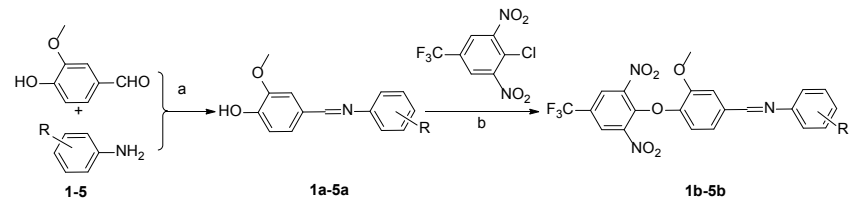

Scheme 1: General route for the synthesis of compounds $\mathbf{1 b}-\mathbf{5 b}$. Reaction and condition: a, EtOH, reflex, $6 \mathrm{~h}$; b, acetone, $\mathrm{K}_{2} \mathrm{CO}_{3}$, reflex, $3 \mathrm{~h}$.
Table 1. In general, all of them showed remarkable inhibition effects on cancer cell proliferation, especially for compound $3 \mathrm{~b}\left(\mathrm{IC}_{50}=1.26 \pm 0.84\right.$ $\mu \mathrm{M})$ which showed a comparable effect to colchicine $\left(\mathrm{IC}_{50}=0.93 \pm 0.46\right.$ $\mu \mathrm{M})$ against MCF-7 cells through inhibiting tubulin polymerization. Additionally, they showed low cytotoxicity towards non-cancer cells when compared with colchicine.

Effects of compound $3 b$ on tubulin polymerization: Then we performed the tubulin assembly assay to examine whether the compounds interact with tubulin and inhibit tubulin polymerization in vitro. As is shown in Table 1, 3b showed the most potent anti-tubulin activity and their $50 \%$ tubulin polymerization inhibition are $5.10 \pm 0.81$ $\mu \mathrm{M}$, which are similar to that of colchicine $\left(\mathrm{IC}_{50}=3.42 \pm 0.63 \mu \mathrm{M}\right)$. In the binding model, compound $3 \mathrm{~b}$ is nicely bound to the colchicine binding site of tubulin via one hydrogen bond with ALA 250 and one $\pi$ bond with CYS 241 (Figure 2A), and the binding energy was $-52.8116 \mathrm{kcal}$. For Figure $2 \mathrm{~B}$, the binding poses of colchicine to tubulin, two hydrogen bonds with VAL 181 and CYS241, and one $\pi$ bond with CYS241 were formed to stabilize the binding between colchicine and tubulin. The binding energy between them was $-55.3687 \mathrm{kcal}$. In view of the binding energy and binding poses, the interaction between compound $3 \mathrm{~b}$ is similar to that of colchicine. The molecular docking results argue that compound $3 \mathrm{~b}$ may be a potential anti-tubulin inhibitor via binding to the colchicine binding site of tubulin and then inhibit tubulin polymerization.

Effects of compound $3 \mathrm{~b}$ on MCF-7 cell cycle distribution: Considering that tubulin could be the target of $3 \mathrm{~b}$, we detected the effect of $3 \mathrm{~b}$ on cell cycle distribution. As shown in Figure 3, MCF-7 cells were treated with $3 \mathrm{~b}$ at different concentrations for $24 \mathrm{~h}$ could arrest cell cycle in $\mathrm{G} 2 / \mathrm{M}$ phase in a time-dependent manner. When the drug concentration was increased to $10 \mu \mathrm{M}, 23.34 \%$ cells were arrest in G2/M phase.
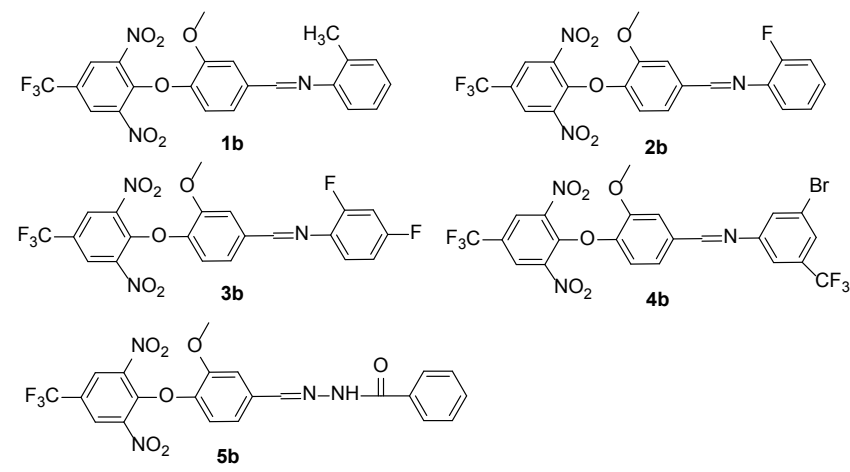

Figure 1: Structure of synthetic compounds $1 \mathrm{~b}-5 \mathrm{~b}$

\begin{tabular}{|c|c|c|c|c|c|}
\hline \multirow{2}{*}{ Compound } & \multicolumn{4}{|c|}{$\mathrm{IC}_{50} \pm \mathrm{SD}^{\mathrm{a}}(\mu \mathrm{M})$} & \multirow[b]{2}{*}{ Tubulin $^{b}$} \\
\hline & MCF-7 & A549 & MDA-MB-231 & L02 & \\
\hline $1 b$ & $3.13 \pm 1.25$ & $4.36 \pm 1.22$ & $3.86 \pm 0.98$ & $78.6 \pm 1.87$ & $11.86 \pm 0.87$ \\
\hline $2 b$ & $4.45 \pm 0.68$ & $4.98 \pm 0.55$ & $5.51 \pm 0.96$ & $86.3 \pm 3.35$ & $6.84 \pm 0.96$ \\
\hline $3 b$ & $1.26 \pm 0.84$ & $2.17 \pm 0.46$ & $3.28 \pm 0.53$ & $98.6 \pm 3.54$ & $5.10 \pm 0.81$ \\
\hline $4 b$ & $5.47 \pm 1.27$ & $1.43 \pm 1.09$ & $5.54 \pm 1.14$ & $76.5 \pm 1.56$ & $8.46 \pm 1.27$ \\
\hline $5 b$ & $2.53 \pm 0.41$ & $3.63 \pm 0.71$ & $3.56 \pm 0.27$ & $88.9 \pm 2.36$ & $10.47 \pm 1.75$ \\
\hline Colchicine & $0.93 \pm 0.46$ & $1.25 \pm 0.67$ & $2.11 \pm 0.97$ & $3.15 \pm 0.56$ & $3.42 \pm 0.63$ \\
\hline
\end{tabular}

alnhibition of the growth of tumor cell lines; ' Inhibition of tubulin polymerization

Table 1: Inhibition ( $\left(\mathrm{C}_{50}\right)$ of MCF-7, A549, MDA-MB-231 cells proliferation and tubulin polymerization by compounds $\mathbf{1 b}-\mathbf{5 b}$ 
Citation: Bai L, Qian H, Jiang D, Wang X, Wang R (2017) Design, Synthesis and Anti-tubulin Activity of Novel Dinitro Diphenyl Ether Derivatives as Potent Anticancer Agent. Med Chem (Los Angeles) 7: 393-397. doi: 10.4172/2161-0444.10486

Effects of compound $3 \mathbf{b}$ on MCF-7 cell apoptosis: We next treated MCF-7 cells with varying concentrations of compound 3 band analysed cells for changes in apoptotic markers by flow cytometer in vitro. As shown in Figure 4, after treated with increasing concentrations of $3 \mathrm{~b}$, the percentage of killed cells has a significant increase. When the concentration increased to $10 \mu \mathrm{M}, 5.13 \%$ and $33.2 \%$ cells presented as early and later apoptosis, respectively.

\section{Conclusion}

In this paper, a series of novel Dinitrodiphenyl Ether derivatives compounds ( $1 b-5 b)$ were synthesized and evaluated their anti-cancer activities. These compounds exhibited potent cell growth inhibitory activities and anti-proliferative activities against human MCF-7, A549 and MDA-MB-231 cell lines. Among them, compound $3 \mathrm{~b}$ showed the most potent inhibition activity with $\mathrm{IC}_{50}$ values of $1.26 \pm 0.84$ $\mu \mathrm{M}$ against human MCF-7 cell line, which was comparable to that of colchicine $\left(\mathrm{IC}_{50}=0.93 \pm 0.46 \mu \mathrm{M}\right)$. In vitro tubulin polymerization assay and molecular docking simulation results demonstrated that $3 \mathrm{~b}$ could bind to the colchicine binding site of tubulin and effectively inhibit tubulin polymerization. Moreover, the subsequent cell cycle arrest
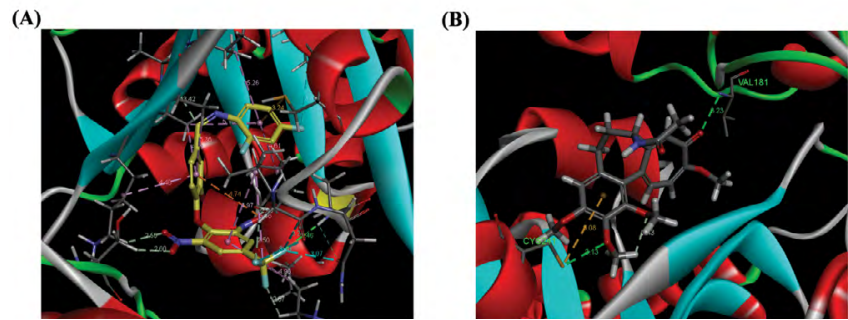

Figure 2: The binding mode between the active conformation of compound $\mathbf{3 b}$ colchicine and the target tubulin (PDB code: $1 \mathrm{sa} 0$ ) provided by the CDOCKER protocol (Discovery Studio 3.5, Accelrys, Co. Ltd).

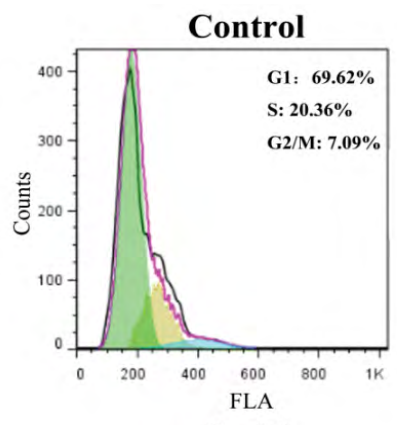

$\mathbf{3} \boldsymbol{\mu M}$

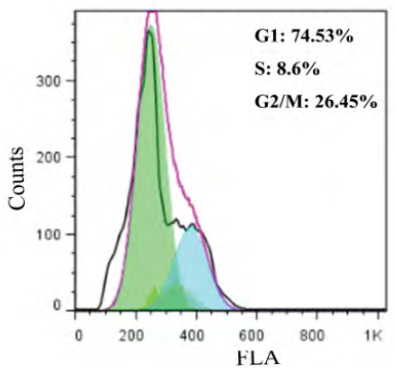

HLA

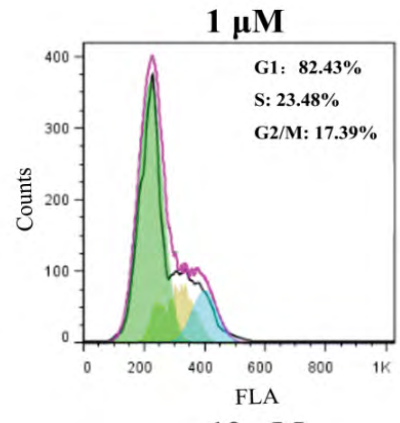

$10 \mu \mathrm{M}$

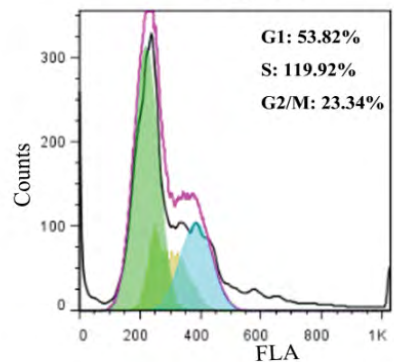

Figure 3: Effect of $3 b$ on the cell cycle distribution of MCF-7 cells (Green, G1 phase; yellow, S phase; blue, G2/M phase).

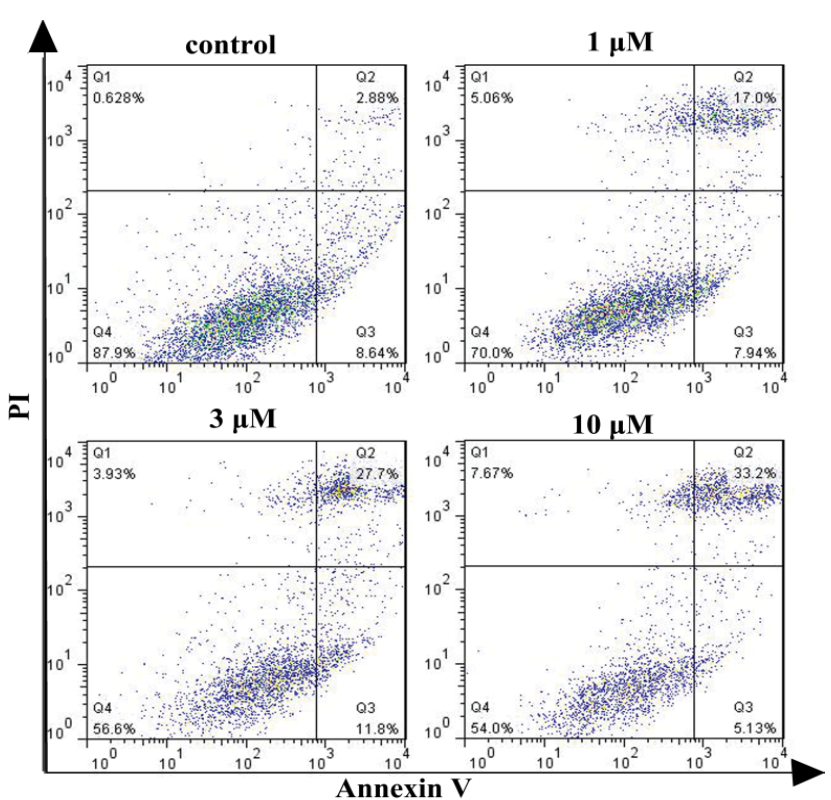

Figure 4: Annexin V/PI dual-immuno-fluorescence staining of MCF-7 cells treated with $3 b$ for $24 \mathrm{~h}$.

and apoptosis assay further confirmed that $3 \mathrm{~b}$ could cause MCF-7 cell cycle arrest in the middle and later stages of mitosis and thus leading to cell apoptosis. To sum up, we recommend $3 \mathrm{~b}$ as the best candidate of potential anti-cancer agent among these new compounds.

\section{Acknowledgments}

This work was supported by the Natural Science Foundation of the Jiangsu Higher Education Institutions of China (Grant No.15KJA350001).

\section{References}

1. Gregory MA, Gabriel CL, Elizabeth HK, Zhang R, David B, et al. (2014) HighResolution Microtubule Structures Reveal the Structural Transitions in $\alpha / \beta$ Tubulin upon GTP Hydrolysis. Cell 157: 1117-1129.

2. Kim MJ, Katarzyna AR (2014) Mechanical Aspects of Microtubule Bundling in Taxane-Treated Circulating Tumor Cells. Biophysical 107: 1236-1246.

3. Wang GC, Peng F, Cao D, Yang Z, Han XL, et al. (2013) Design, synthesis and biological evaluation of millepachine derivatives as a new class of tubulin polymerization inhibitors. Bioorg Med Chem 21: 6844-6854.

4. Iwao O, Kunal K, Divya A, Jacob GV (2014) Drug discovery targeting cell division proteins, microtubules and FtsZ. Bioorg Med Chem 22: 5060-5077.

5. Jessica JF, José FD, John HM (2013) The Binding Sites of MicrotubuleStabilizing Agents. Chem Biol 20: 301-315.

6. Marta MD, María JGN, Benet P, Benjamin PB, Juan FML, et al. (2014) PM060184, a new tubulin binding agent with potent anti-tumor activity including P-glycoprotein over-expressing tumors. Biochem Pharmacol 88: 291-302.

7. Yao YF, Wang ZC, Wu SY, Li QF, Yu C, et al. (2017) Identification of nove 1-indolyl acetate-5-nitroimidazole derivatives of combretastatin A-4 as potential tubulin polymerization inhibitors. Biochem Pharmacol 137: 10-28.

8. Wang YT, Cai X, Shi TQ, Zhang YL, Wang ZC, et al. (2017) Synthesis, molecular docking and biological evaluation of 1-phenylsulphonyl-2-(1methylindol-3-yl)-benzimidazole derivatives as novel potential tubulin assembling inhibitors. Chem Bio Drug Des 90: 112-118.

9. Malebari AM, Greene LM, Nathwani SM, Fayne D, O'Boyle NM, et al. (2017) $\beta$-Lactam analogues of combretastatin A-4 prevent metabolic inactivation by glucuronidation in chemoresistant HT-29 colon cancer cells. Eur J Med Chem 130: $261-285$.

10. Sun $M, X u Q, X u J, W u Y$, Wang $Y$, et al. (2017) Synthesis and bioevaluation 
Citation: Bai L, Qian H, Jiang D, Wang X, Wang R (2017) Design, Synthesis and Anti-tubulin Activity of Novel Dinitro Diphenyl Ether Derivatives as Potent Anticancer Agent. Med Chem (Los Angeles) 7: 393-397. doi: 10.4172/2161-0444.10486

of N,4-diaryl-1,3-thiazole-2-amines as tubulin inhibitors with potent antiproliferative activity. Plos One 12: e0174006.

11. El-halim HFA, Omar M, Mohamed GG (2011) Synthesis, structural, thermal studies and biological activity of a tridentate Schiff base ligand and their transition metal complexes, Spectrochimica Acta Part A: Molecular and Biomolecular Spectroscopy 78: 36-44.

12. Ravoof TB, Crouse KA, Tahir MIM, How FN, Rosli R, et al. (2010) Synthesis, characterization and biological activities of 3-methylbenzyl 2-(6-methyl pyridin2-ylmethylene) hydrazine carbodithioate and its transition metal complexes, Transition Metal Chemistry 35871-35876.

13. Baul TSB, Basu S, Vos D, Linden A (2009) Amino acetate functionalized Schiff base organotin (IV) complexes as anticancer drugs: synthesis, structural characterization, and in vitro cytotoxicity studies, Investigational New Drugs 27: 419-431.

14. Zhao TT, Lu X, Yang XH, Wang LM, Li X, et al. (2012) Synthesis, biological evaluation, and molecular docking studies of 2,6-dinitro-4-(trifluoromethyl) phenoxysalicylaldoxime derivatives as novel antitubulin agents. Bioorg Med Chem 20: 3233-3241.

15. George TG, Johnsamuel J, Delfín DA, Yakovich A, Mukherjee M, et al. (2006) Antikinetoplastid antimitotic activity and metabolic stability of Dinitrodiphenyl Ether sulfonamides and benzamides. Bioorg Med Chem 14: 5699-5710.

16. Fennell BJ, Naughton JA, Dempsey E, Bell A (2006) Cellular and molecular actions of Dinitrodiphenyl Ether and phosphorothioamidate herbicides on Plasmodium falciparum: Tubulin as a specific antimalarial target. Mol Biochem Parasitol 145: 226-238. 